\title{
ACCENTUATING THE POSITIVE ORGANIZATIONAL BEHAVIOUR AND WORK ENGAGEMENT CONCEPTS TOWARDS JOB PERFORMANCE QUALITY OF PUBLIC SECTOR STAFF IN WILAYAH PERSEKUTUAN PUTRAJAYA
}

\author{
Nordayana Zulkifli, Dr. Kalsom binti Ali \\ Universiti Sains Islam Malaysia (USIM) Bandar Baru Nilai, 71800, Nilai, Negeri Sembilan, Malaysia ${ }^{1.2}$ \\ nordayanazulkifli@gmail.com ${ }^{1}, \underline{\text { kalsom@usim.edu.my }{ }^{2}}$
}

Article History: Received on $17^{\text {th }}$ July, Final Revised on $20^{\text {th }}$ September, Published on 30 $30^{\text {th }}$ September 2017

\begin{abstract}
The modern concept of positive psychology movement and the need for an organization to adopt and adapt positive approach towards the organizational behaviour and culture in public organization has emerged. The organization needs to embrace a proactive and encouraging approach and not highlighting the negativity towards their staff.

Hence, this study will be directed to answer the utilization of positive organization behaviour (POB) theory to encourage the actual state-like psychological resource capacities such as self-efficacy, hope, optimism, and resilience to ascertain workforce capabilities and issues of job performance quality aspects of in-role behaviour and extra-role behaviour, which the researcher believes it can contribute to the development of the workforce. The questions and relationship of many factors towards job performance quality has been widely debated in human resources field, with scholars discusses various facets such as psychological well-being, performance appraisal, and workplace environment, however the application and implementation of POB are still less discussed in the Asia country as a whole and Malaysia context as compared to the Western region.
\end{abstract}

This study will also examine the moderating effects of work engagement on the relationship of POB and job performance capabilities among public sector staff in Wilayah Persekutuan Putrajaya, which focuses to the "Pegawai Tadbir dan Diplomatik" (PTD) officer with the current service year maximum of 5 years. Data will be collected via questionnaires and the study will be using SPSS and AMOS to analyse the data. A quantitative study will be conducted towards the process of gaining data and a result regarding $\mathrm{POB}$, work engagement and job performance quality to uncover the philosophy of organizational behaviour with the psychology adding concept and directly it hopes to reveal its antecedents and consequences.

Even though the public sector had undergone massive transformation since past few years, the skills, mind set and application of work behaviour needs to be review comprehensively. Therefore, the findings will be expected to show the effects of POB and work engagement in job performance capabilities which substantial for the public sector staff in order to improve their service quality and higher performance.

Keywords: Job performance quality; positive organizational behaviour; work engagement; workforce capabilities; psychological capital.

\section{INTRODUCTION}

In the modern and fast challenging world today, organizations are under pressure to achieve maximum work standard quality and to produce proactive, energetic and dedicated employees towards their jobs and working environment. As mentioned by Haenisch (2012), workforce productivity remains a major element for organizations success including those in government sector. Knowing the influential factors of productivity booster and job quality elements is the prerequisite to improve organizational productivity and become a necessity. Previous studies shows that numerous elements demonstrated the successful implementation of job performance quality; firstly, Byrnes (2006) highlighted the power of performance based on compensation and study by Fleishman (1973) emphasized on the leadership behaviour. Job performance quality is a worldwide problem which troubled companies all over the world and fuelled a great deal of research in the field of management, occupational health, work and organizational psychology (Koopmans et.al, 2011). The relationship of many factors towards job performance quality has been studies worldwide including stress and psychological well-being (Jasmani \& Abdul, 2011), performance appraisal and commitment (Munir et. al., 2012), workplace environment (Nur \& Narehan, 2015) and work motivation (Mahazril et. al., 2012). The emergence of positive workplace environment and positive approaches in handling staffs, stakeholders and organization as a whole tends to create an understanding and implementing organization as a vibrant, approachable behaviour. It is a crucial and become an integral part of business success in modern practice organization. Employees who exhibit higher level of satisfaction tend to work beyond effort such as in role performances and extra role performances (Wong et.al, 2014). 
Job performance quality always capture the mind set of organization as it is the most vital aspects in holding employees commitment towards organization which can directly influence the organization successfulness (Pushpa kumari, 2008). The fun and happiness of each and every individual in the organization will particularly achieve higher level of employee job performance quality (Proctor, 2014). In the contemporary world of work challenges and organization competition to become the best among the best, they need the employees that are committed to their profession, and participate fully in their normal job roles to achieve excellent job standards. All this can only be fulfilled with a fun and supporting job environment as supported by Gorgievski et.al. 2010. Instead of highlighting the negative perspective of organization behaviour, Positive Organization Behaviour (POB) had become a new concept that focusing employee's strength rather than weaknesses which is important in developing their inner capabilities and interest towards their job. Luthans (2002) stated that POB is application of positive human resource approaches which can be restrained, established, and successfully accomplished for performance improvement in today's workplace. Expand research done by Luthans \& Youssef (2007) suggested Psychological Capital (PsyCap) concept of self-efficacy, hope, optimism, and resiliency as four key psychological resource capacities that best meet the inclusion criteria for POB, which enhances managing effectiveness and organizational performance. Modern management style need to adapt POB as it describes and focuses on the establishment yet the development of staff towards a better work performance. Strengthen by Peterson (2006) as cited in Youssef \& Luthans (2007) who quotes "what is good about life is as genuine as what is bad and therefore deserves equal attention". Although, recent practices emphasized the traditional implementation of human resource in the organization, top management need to adapt and understand the modern concept of POB to be applied in the organization. POB are the combinations of psychological and human resource relationship that highlighted the grooming of employees positive well-being and attractive personality. Meanwhile, the concept of work engagement is emerged in the recent years and become a polemic in every organization that strives for a high performance of the staff. Utrecht Work Engagement Scale (UWES) divides work engagement into three sub points that link directly towards quality of staff performance in the organization. The three subscales are vigor, dedication and absorption. An engaged staff are expected to be more enthusiastic and determined towards their jobs and engaged in their job higher than others. To survive and develop in the competitive advantage, organizations need to expand and adjust to several changes. Despite of the policies, procedural transformation and various facet of management revolutionary, the global changes in managing human capital are evolved and the significance of the multi-level staffs to be part of the transformation are become priority. Organizations start to conduct several programs and the objectives of all the interferences are to growth organization and employee performance by affecting employee behaviour towards their profession. (Welbourne, Johnson \& Erez, 1997).

\section{STATEMENT OF THE PROBLEM}

The problem statement is about the job performance quality of public sector staff in the context of Federal Government agency in Putrajaya. There are many issues on the job performance relating to public sector staff. Started on 1989 , current Prime Minister at the time, Tun Dr Mahathir Mohamad introduced "Gerakan Budaya Kerja Cemerlang" (excellence work ethics) as an initiative to improve staff productivity towards their jobs. Former Prime Minister of Malaysia, Tun Dr. Mahathir Mohamad once stated that the strive of quality enhancement do not have any time limit and it shall be developed without a full stop. Theories concerning job satisfaction and job performance are still weak, empirical studies provide mixed result and the situation of staff attitude - performance needs further investigation . Public service employee formed the backbone of public service delivery and their capacity to facilitate the evolving national agenda largely determines the success of public policies. With the challenge posed by globalization and the huge growth of technology, the employees in every organization are required to be on top of their performance and prove that there is a critical need for highest job performance quality achieve by every individual in the organization especially the public sector.

This challenges are even more significant in Malaysia context as this country are moving towards full performances and achievement geared by the staffs. Public organization are in a high race to establish a high performance staff to eliminate previous perceptions towards the job performance quality of their staff. In order to improve and enhance job performance in the organization, human capital should be prioritized and analyzed in a workplace setting (Luthans \& Peterson, 2002) by engaging the theory with work engagement that can directly improve job performances from the ; in role (IR) and extra role (ER) perspectives. Luthans (2002) also emphasized the need for a real search for and understanding of the good in people, in every aspect; workplace and personal. POB seems is the way of organizations main strategies as an exciting step to treasure as human capital have infinite power if they are manage accordingly. Since organizations in Malaysia especially in public sector agencies have been transformed and performed multiple work demands, the lifestyle of extra working hours and workaholic condition that affected the job performance quality are expanding and it is essential to escalate the significance of POB by promoting work engagement in the workplace that can lead the staff into job performance quality (in-role and extra-role). 


\section{PURPOSE OF THE STUDY}

This study will directly involve with the performance of the staff quality and physical well-being. The workplace revolutions have been transforming from 8 hours sessions into a longer period with other job tasks and responsibilities. It is very significant theoretically to adapt and develop new approach to organizational behaviour introduced by Luthans (2002) ; Positive Organization Behaviour (POB) into the workplace with the aid of moderating factors of Work Engagement (Schaufeli et, al. 2002) in order to strive job performance quality from the staff in every organization. Hence, the POB concept creates a framework which the elements can be investigated and tested to enhance job performance quality in the selected organization. In the active and challenging work environment organization, a great emphasis that focuses towards human capital need to be adapted and recognized, and an excellent organization shall foster the elements of POB and work engagement if they want to increase the JPQ among their employees. It is essential to understand the need and meaning of a positive approach to organizational behaviour perspective and scamper from traditional method applied in the organization. The organization needs a proactive and positive approach that focuses on strength rather than enduring the negativity aspect towards their staff. The general objectives envision towards this study are generalised as below:

i. To examine the efficacy of positive organizational behaviour (POB) components towards job performance quality (JPQ);

ii. To investigate the relationship between POB and JPQ ;

iii. To examine the moderating effects of work engagement criteria towards POB and JPQ.

\section{Limitation of the Study}

The study is limited to the public sector staffs holding the position as Pegawai Tadbir dan Diplomatik (PTD) with the salary scheme of M41 with less than 5 years of service currently employed in Putrajaya only.

\section{LITERATURE REVIEW}

\section{Introduction}

In recent years, numerous approaches and strategies are developed to improve job performance quality. These include a detailed study and analysis of many aspects of organizations (human resource, material resources, and motivation, financial) and much more. The investigation of the relationship between positive organizational behaviour (POB) and training is still in its early stages. Although there have been several studies reported on this concept and job performance quality (JPQ), specifically PsyCap in foreign countries, very little has been done in Malaysia especially for the public sector agency. To the date, several major researchers regarding POB in the organizations enable the concept to emerge and become more unique and positive day by day. (Luthans, 2002; Luthans \& Youssef, 2007; Nelson \& Cooper, 2007). However, there is always an attempt to study this concept with a current situation and with different organizations and job roles. This research is an attempt to explore prevalence between four selected POB concept (self-efficacy, hope, optimism, and resiliency), towards JPQ (in-role and extra-role performance) by using a moderating factor of work engagement (vigor, dedication, and absorption). Since the POB concept has been introduced and highlighted by Luthans (2002), many types of research have been tested and done worldwide to enhance the implementation of this theory into organizations. However, the practitioner still in doubt to fully utilize the POB concept as it needed a new paradigm to conduct.

\section{Job Performance Quality}

Job performance represents behaviour the staff engaged at work that they can contribute to the achievement of organizations goal setting. Job performance is an abstract, latent construct that cannot be pointed to or measured directly and it was made up of multiple components or dimensions (Koopmans et.al, 2011). Campbell (1990) in the Koopmans et. al (2011) mentioned job performance is a behaviours or activities that are relevant to the achieve the aims of the organization." Three philosophies complement this definition: (1) work performance should be defined regarding behaviour rather than results, (2) work performance includes only those behaviours that are relevant to the organization's goals, and (3) work performance is multidimensional.

\section{In-Role Performance Behaviour / Extra-Role Performance Behaviour}

In-role behaviour performance is most described as task performance. It is the proficiency or the competency for one person to perform the central job task. The performance of each task can differ from job-to-job. Meanwhile, extra-role performance behaviours are the behaviours of the employees towards their willingness to do the job beyond their job description and job specifications to help in the smooth functioning of the organization as a social system. A thorough study and analysis of many aspects in organizations (human resource, material resources, and motivation, financial) have been developed over the years. Meanwhile, the investigation of the relationship between POB and training is still in its
136 
early stages. Although there have been several studies reported on this concept and JPQ, specifically PsyCap in foreign countries, very little has been done in Malaysia especially for the public sector agency.

To date, several major types of research regarding $\mathrm{POB}$ in the organizations enable the concept to emerge and become more unique and positive day by day. (Luthans, 2002; Luthans \& Youssef, 2007; Nelson \& Cooper, 2007). However, there is always an attempt to study this concept with a current situation and with a different organizations and job roles. This research is an attempt to explore prevalence between four selected POB concept (self-efficacy, hope, optimism and resiliency), towards JPQ (in-role and extra-role performance) by using a moderating factor of work engagement (vigor, dedication and absorption).

\section{Positive Organizational Behaviour (POB)}

This concept focuses on the real organization (staff as a priority) instead of fixing the weaknesses. With the enormous changes in the way of organization conduct, it has been recognizes that over the years, many positive construct has been applied in the organization includes positive affectivity, positive reinforcement, job satisfaction and commitment, selfevaluation and many others. By adopting positive psychology into the workplace situation using POB, it will give a renewed emphasis to the importance of positive approach. (Youssef \& Luthans, 2007). POB highlighted the importance of more positive approach need to be applied not only in a psychology, but also in management and business field, derived from the research done by Walsh, Weber and Margolis (2003) who reported that the in the management and business field, negative biased words have increased four-fold compared to the positive terms. Typically, POB determined and strengthen into individual (staff) positive psychological conditions and human resource strengths-relates to the individual well-being and performance quality improvement. The four (4) factors have been studied worldwide regarding POB like self-efficacy, hope, optimism and resiliency in coping with the organizational demands or in fostering performance (Bakker \& Schaufeli, 2008).

\section{Self-Efficacy}

Self-efficacy is defined as having self-confidence to take responsibility and the necessary effort to succeed at stimulating tasks. The determination and courage to take the responsibilities given by the superior will challenge each and every individual how to survive and make it success. As described by Bandura (1982), self-efficacy affects learning and performance in three ways, which are self-efficacy, influences the goals that employees choose for themselves, selfefficacy influences learning as well as the effort that people exert on the job and self-efficacy influences the persistence with which people attempt new and difficult tasks. Employees with high self-efficacy are confident that they can learn and perform a specific task. Every organization can reassure greater performance goals from staffs that have a high level of self-efficacy. It will lead to higher level of performance, which is critical for many organizations in the era of high competition (Malik, 2013).

\section{Hope}

Hope has been defined as positive approach that is based on an interactively derived sense of successful agency and paths. (Snyder et. al, 2000). Hope has been shown to be applicable and relate to various performance factors like the workplace and the people inside the organization. (Luthans, et. al. 2005). Human resources with a higher hope are more profitable, higher retention rates and have greater satisfaction and commitment towards their jobs and well-being. (Snyder et. al, 2000). Hope is not an emotion but it more directly link to dynamic cognitive motivational system. (Snyder et.al, 1991) Meanwhile, Pekrun, Elliot, Maier (2006) see hope as one of the academic achievement emotions resulting from mastery and performance-approach goals.

\section{Optimism}

A famous quote by Winston Churchill, "a pessimist sees the difficulty in every opportunity; an optimist sees the opportunity in every difficulty." Optimism has been proven as an agent to increase the protected system and so as the reliever to stressful news. Gratitude is associated with optimism and has been determined that grateful people are happier, receive more social support, are less stressed, and are less depressed. Recent research indicates that optimists and pessimists' person are approaching problems differently, and their ability to cope successfully with adversity differs. As highlighted by Scheier \& Carver (1985) , optimism is a set of generalized positive outcome expectancies. Furthermore, as cited by Malik (2013) in Strutton \& Lumpkin (1992), it was found that the optimism -performance relationship was moderated by the type of copying tactics used to deal with stress in the workplace. They showed that optimistic individuals used more problems - focused coping strategies and that they outperformed pessimistic individuals in the work environment. A small number of studies regarding optimism on performance and work related behaviour strengthen the concept need to be generalized and modernized in order to cope with the new environment of organizational climate. 


\section{Resiliency}

Malik (2013) stated that resilience is the capability and aptitude of a place of work to ensure potential significant commotions by adapting, recovering or resisting being affected and resuming core operations or continuing to provide an acceptable level of functioning and structure. It is the ability to respond quickly. Eventually, it is the accountability of those in leadership roles (managers and supervisors) to generate an organization climate that nurtures well-being and assists resilience. Intense and unpleasant demands tend to overload people, especially when the demands are unrelenting and there is insufficient time to regain balance. Even when people are coping well and stress levels are low, prolonged over-demand can lead to burn out and a subsequent negative impact on workers as well as the economy of an organization (Hiebert, 2006)

\section{Work Engagement}

Work engagement is an organizational method planned to ensure that employees are devoted to their organization's goals and beliefs, motivated to contribute to organizational success, and are able at the same time to enhance their own sense of well-being. Besides, scholars defined engagement as a positive, fulfilling, work-related state of mind that is characterized by vigor, dedication, and absorption. (Schaufeli, 2002). Whilst, Bakker and Schaufeli (2008) highlighted the need for positive organizational behaviour (POB), the need for work engagement to be constructed into this mechanism is also arise. Numerous researches done by Schaufeli et.al (2002) showed that engaged employees have a high energy level and self-efficacy which assist them to implement influence over events that affect their lives. Engaged employees are not a superhero, they do feel tired after a tiring session of working hours, however, the tiredness are transform into a pleasant state of mind because they associated it with the positive minds and behaviours.

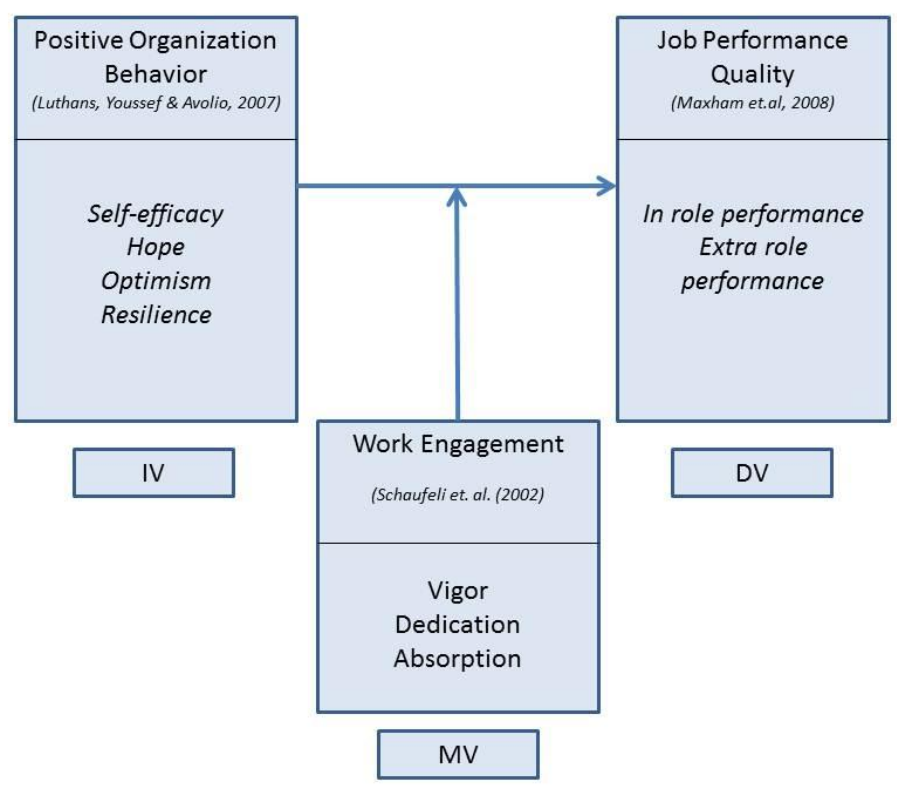

Figure 1: Conceptual Framework: Accentuating the Positive Organizational Behavior and Work Engagement Concepts towards Job Performance Quality of Public Sector Staff in Putrajaya, Malaysia

\section{METHODOLOGY}

\section{Introduction}

The purpose of this study is to investigate the relationship between POB and JPQ and to examine the moderating effect of work engagement towards POB and JPQ. Furthermore, this study attempts to analyze the concept of psychology in organizational behaviour which is focusing on positivity aspect rather than fixing weaknesses.

\section{Research Design}

This research is a regression coefficient research as it examines the relationship between variables by using a moderator. If the moderator variables found to be significant, it can cause an amplifying or weakening effect between variables. This research will illustrate a great picture of the variables under POB in order create a high job performance quality in the organization by using work engagement variables as a moderator. 


\section{Population and Sampling}

The sampling frame is a list of all the individual sampling units (elements) in the population. (Friedrich, 2000) The sampling frame that will be used for this research is based on a list of the PTD with the salary scheme of M41 and having less than 5 years of service. The sampling frame will be obtained from Bahagian Khidmat Pengurusan, Jabatan Perkhidmatan Awam Malaysia (JPA). To select the respondent for this study, the stratified random sampling will be used. According to Salkind (2003), stratified sampling is important to ensure that the strata (or layers) of the population are fairly represented in the sample. The total populations of each specific group are used, sampling bias, nonindependent or unequal chance of selecting a sample is not an issue. The results obtained from this technique maybe are natural interest and can be analyzed separately. For this study, the researcher will used sample size suggested by Krejcie \& Morgan (1970) as cited in Sekaran (2006) which stated that sample size could be simplified by providing a table that ensures a good decision model. The population gained for this research are approximately 1000 staff serviced as PTD (M41 and less than 5 years of service) currently employed in Putrajaya.

\section{Survey Instruments}

The instrument will be used for the data collection is an online survey questionnaire. The questionnaires are the combination of the open ended questions, close ended with free answers, and two types of five-point Likert Scale basis with the following values: (1) Strongly Agree, (2) Disagree, (3) No Opinion, (4) Agree and (5) Strongly Agree. Another type of five-point Likert Scale values was as follow: (1) Not Important, (2) Least Important, (3) Uncertain, (4) Important and (5) Most Important.

The questionnaires will be divided into five (5) sections, Section A, B, C, D, and E. Section A will analyze the demographic background of the respondents which consists the designation, duration of service, qualifications, salary range, gender, marital status and age of the respondent. Next, Section B until Section E will comprehensively illustrate the question from every variable involved. An online survey will be developed by the researcher, and the questionnaire will be emailed to each respondent selected within the time frame.

\section{Reliability and Validity of Instruments}

According to Sekaran (2006), the reliability of the instruments indicates the extent to which the study is error free and ensures the measurement is consistent across time and the various items in the instruments. The study will have consistent results if repeated over time or if used by two different researchers. To examine the reliability of the study, the instruments will be sent to a pilot study to test the normality before it is used in the real set of questionnaire. Meanwhile, according to McMillan and Schumacher (2006), the validity of instruments is the extent to which users made by scores are reasonable and appropriate. The questionnaire will be tested for both face and content validity by experts who check for errors, ambiguity, and concept. One (1) lecturer in the area of concern will establish the face validity and one (1) expert from the industry will be consulted to review this study. The feedback that gathered from these experts will assist in improving the instrument.

\section{Implications of the Study}

This study is predicted to several implications whereby it is hope to develop the awareness and accentuate job performance quality in the organization. The issues of job performance are always been debated for years yet it is still become the overall polemic in every organizations. By implementing and suggesting the proposed model of POB and work engagement into the overall picture, the researcher optimised to set a culture of preventive action rather than fixing in order to circumvent more problems in the future. Higher job performance will create a more powerful employees and powerful organization as a whole.

\section{REFERENCES}

1. Akshay Malik, (2013) Efficacy, Hope, Optimism, and Resilience at Workplace - Positive Organizational Behaviour. International Journal of Scientific and Research Publications. Vol. 3 (10)

2. Bandura A. (1982) Self Efficacy Mechanism in Human Agency. American Psychologist. Vol. 37 (2). http://psycnet.apa.org/doi/10.1037/0003-066X.37.2.122

3. Byrnes (2006). The art of motivation. Business Week, pp. 57-62.

4. Campbell, J.P. (1990). Modeling The Performance Prediction Problem In Industrial And Organizational Psychology. In M.D. Dunnette and L.M. Hough (Eds.), Handbook of Role-Based Performance Scale Psychology, Vol. 1 (2) pp 687-732.

5. Fleishman E. A. (1973). Twenty years of consideration and structure. In Fleishman E. A., Hunt J. G. (Eds.), Current developments in the study of leadership (pp. 1-37). Carbondale: Southern Illinois University Press.

6. Friedrich, G.W. (2000). Methods of Inquiry: Sampling Theory. Retrieved April 1, 2015, from www.scils.rutgers.edu. 
7. Gorgievski, M.J., Bakker, A.B. \& Schaufeli, W.B. (2010). Work engagement and workaholism: Comparing the selfemployed and slaried employees. The Journal of Positive Psychology, 5(1), 83-96. http://dx.doi.org/10.1080/17439760903509606

8. Jasmani, M.Y. \& Mahajar, A. J. (2011). Stress and psychological well-being of government officers in Malaysia. The Journal of Human Resource and Adult Learning, 7(2), 40.

9. Haenisch J. P. (2012). Factors Affecting the Productivity of Government Workers. Sage Journals. Vol. 2 (1). https://doi.org/10.1177/2158244012441603

10. Hiebert, b. (2006). A Contemporary Look at Stress and Burnout: Clarifying the Nuances. The Alberta Counsellor, 29(1), 16-25. Retrieved April 1, 2015, from www.ijsrp.org.

11. Koopmans, L., Bernaards, C. M., Hildebrandt, V. H., Schaufeli, W. B., De Vet, H. C. W., \& Van der Beek, A. J. (2011). Conceptual Frameworks of Individual Work Performance: A Systematic Review. Journal of Occupational and Environmental Medicine, 53, 856-866. https://doi.org/10.1097/JOM.0b013e318226a763

12. Krejcie, R.V. \& Morgan, D.W. (1970). Determining Sample Size for Research Activities. Educational \& Psychological Measurement. Vol. 30. Pp 607-610.

13. Luthans, F. (2002), Positive Organizational Behaviour: Developing and Managing Psychological Strengths, Academy of Management Executive, Vol. 16, pp. 57-72. https://doi.org/10.5465/AME.2002.6640181

14. Luthans, F. and Youssef, C.M. (2007), Emerging Positive Organizational Behaviour, Journal of Management, Vol. 33, pp. 321-49. https://doi.org/10.1177/0149206307300814

15. Luthans, F. \& Peterson, S.J. (2002) "Employee Engagement and Manager Self-Efficacy". Journal of Management Development. Vol. 21(5). pp.376-387. https://doi.org/10.1108/02621710210426864

16. Luthans, F., Avolio, B. J., Walumbwa, F. O. and Li, W. (2005), The Psychological Capital of Chinese Workers: Exploring the Relationship with Performance. Management and Organization Review, 1: 249-271.

17. Mahazril A.Y., Zuraini Y.Z., Hafizah H.A.K., Aminuddin A., Zakaria Z., Noordin N., Mohamed B.A. (2012) Work Motivation among Malaysian Public Servants. Asian Social Science, 8 (12) , pp. 238-242. http://dx.doi.org/10.5539/ass.v8n12p238

18. Maxham JGI, Netemeyer RG, Lichtenstein DR. The Retail Value Chain: Linking Employee Perceptions to Employee Performance, Customer Evaluations, and Store Performance. Market Sci. 2008; 27:147-167. https://doi.org/10.1287/mksc. 1070.0282

19. Munir, S. Muhammad, J.M. \& Mohammad, S. (2012). The Impact of Job Satisfaction on organizational Commitment. A Study of Faculty Members of Private Universities.Vol. 3(11). Pp 799-808.

20. Nelson, D. \& Cooper, C.L. (2007). Positive Organizational Behavior : Accentuating Positive at Work. Yhousand Oaks, California: Sage.

21. Nur, Z. \& Narehan, H. (2015). The Relationship between Workplace Environment and Job Performance in Selected Government Offices in Shah Alam, Selangor. International Review of Management and Business Research. Vol. 4 (3).

22. Pekrun, R., Elliot, A. J., \& Maier, M. A. (2006). Achievement Goals and Discrete Achievement Emotions: A Theoretical Model and Prospective Test. Journal of Educational Psychology, 98, 583-597. https://doi.org/10.1037/0022-0663.98.3.583

23. Proctor, C. (2014) Effective Organizational Communication Affects Employee Attitude, Happiness and Job Satisfaction. Master Dissertation. Southern Utah University.

24. Pushpakumari, M.D. (2008). The Impact of Job satisfaction on Job Performance: An Empirical Analysis. Pp 89105.

25. Salkind, Neil J. (2003). Exploring Research. $5^{\text {th }}$ ed. New Jersey: Prentice Hall.

26. Schaufeli, W.B., Salanova, M., González-Romá, V., \& Bakker, A. B. (2002). The Measurement Of Engagement And Burnout: A Confirmative Analytic Approach. Journal of Happiness Studies, vol. 3, 71-92 https://doi.org/10.1023/A:1015630930326

27. Sekaran, Uma. (2006). Research Methods for Business: A Skill Building Approach. $4^{\text {th }}$ ed. New Delhi: Wiley India.

28. Scheier, M. F., \& Carver, C. S. (1985). Optimism, Coping, and Health: Assessment and Implications of Generalized Outcome Expectancies. Health Psychology, 4 (3), 219-247. https://doi.org/10.1037/0278-6133.4.3.219

29. Snyder, C. R., Kevin L. Rand, and David R. Sigmon (2002). Hope Theory: A Member of the Positive Psychology Family. in Handbook of Positive Psychology, C. R. Snyder and Shane J. Lopez, eds. Oxford, UK: Oxford University Press, 257-276.

30. Strutton, D., and J. Lumpkin.(1992)Relationship Between Optimism and Coping Strategies in the Work Environment. Psychological Reports, Vol. 71, No. 3, pp. 1179-1186. https://doi.org/10.2466/pr0.1992.71.3f.1179

31. Walsh, J. P., Weber, K., \& Margolis, J. D. (2003). Social issues in management: Our lost case found. Journal ofManagement,29, 859-881. https://doi.org/10.1016/S0149-2063 03 00082-5

32. Welbourne, T. M., Johnson, D. E. \& Erez, A. (1997). The Role-Based Performance Scale: Validity Analysis Of A Theory-Based Measure. Retrieved April 1, 2014015 from digitalcommons.ilr.cornell.edu. 